\title{
The Number of Bacteria, Antioxidant Capacity, and Organoleptic Properties of Red Ginger Fried Chicken
}

\author{
Lismi Animatul Chisbiyaha, ${ }^{\mathrm{a} b}$, Mazarina Devi ${ }^{\mathrm{b}^{*}}$, Issutarti ${ }^{\mathrm{b}}$ \\ ${ }^{a}$ National Yunlin University of Science and Technology Taiwan, University road section 3 Doulio, Yunlin 64002, Taiwan \\ ${ }^{b}$ Department of Industrial Technology, Universitas Negeri Malang, Jl. Semarang No. 5, Malang 65145, Indonesia \\ mazarina.devi.ft@um.ac.id* \\ * corresponding author
}

Article history:

Received: 04-01-2021

Revised: 02-03-2021

Accepted: 28-04-2021

Keywords:

Alpinia purpurata (Vieill.) K.

Schum

bacteria number

antioxidant capacity

organoleptic

\begin{abstract}
Alpinia purpurata (Vieill.) K. Schum is a spice that has the ability to inhibit bacterial growth and has a good antioxidant capacity. This study aims to determine the effect of adding Alpinia purpurata (Vieill.) K. Schum 0\%, 10\%, $20 \%, 30 \%, 40 \%$ on day 0,1 , and 2 on the number of bacteria, antioxidant capacity and hedonic properties which include the taste, aroma, and color of Red ginger fried chicken. This type of research was an experimental research with a completely randomized factorial design (CRD). The data obtained were then analyzed statistically using ANOVA and continued with Duncan's Multiple Range Test (DMRT) to obtained differences. Each treatment was repeated twice. The results showed that the addition of the concentration of Alpinia purpurata (Vieill.) K. Schum 0\%, 10\%, 20\%, 30\% and 40\% in Red ginger fried chicken had a significant effect on the number of bacteria and antioxidant capacity on day 0 , 1,2 and had a significant effect on the hedonic properties on day 0 . (taste, color and aroma) on the hedonic properties on day 0. (taste, color and aroma). The addition of Alpinia purpurata (Vieill.) K. Schum $40 \%$ gave the best results on the number of bacteria, antioxidant capacity and hedonic properties. To conclude, the higher the addition of Alpinia purpurata (Vieill.) K. Schum to Red ginger fried chicken resulted on the lower the number of bacteria and the greater the antioxidant capacity and the more preferred hedonic properties.
\end{abstract}

\section{Introduction}

Alpinia purpurata (Vieill.) K. Schum or red ginger is a spice and seasoning that is frequently used as a flavoring ingredient in Indonesian cuisine. Apart from being used as a kitchen spice, Alpinia purpurata (Vieill.) K. Schum contains ingredients that are typically used as traditional medicine. Consumption of Alpinia purpurata (Vieill.) K. Schum for a long time is able to prevent cancer (Raj et al., 2012). Alpinia purpurata (Vieill.) K. Schum has the potential to act as an antidote to disarm free radicals and protect against oxidative stress that causes degenerative diseases (Lobo et al., 2010). In the future, Alpinia purpurat can be used as a potential drug therapy (Ghosh \& Rangan, 2013). Alpinia purpurata (Vieill.) K. Schum rhizome contains phenolic compounds as antimicrobials (Chan \& Wong, 2015). The role of Alpinia purpurata (Vieill.) K. Schum is as a food preservative that contains antimicrobial activity (de Cuffa Matusaiki et al., 2021; Soares et al., 2018). The chemical compounds contained in Alpinia purpurata (Vieill.) K. Schum are phenols, flavonoids and essential oils (Victório et al., 2009). Phenolic compounds and flavonoids are natural sources of antioxidants that are typically found in vegetation (Tungmunnithum et al., 2018). Within the rhizome of Red Alpinia purpurata (Vieill.) K. Schum, it contains phenolic compounds and flavonoids which can be used as a source of natural antioxidants (Villaflores et al., 2010).

The antioxidant activity in Alpinia purpurata (Vieill.) K. Schum is able to function as a substance to minimize the occurrence of oxidation processes, decomposition, and extend the storage duration of a product (Raj et al., 2012). Alpinia purpurata (Vieill.) K. Schum contains chemicals that is able to prevent or inhibit the growth of microorganisms (Chan \& Wong, 2015). The addition of immature Alpinia purpurata (Vieill.) K. Schum with a concentration of $100 \mathrm{gr} /$ three liters carried out in boiling 
water of meatballs in a boiling state is able to increase the storage duration of meatballs. Besides being able to increase the storage duration of meatballs, the use of Alpinia purpurata (Vieill.) K. Schum extract at a dose of 15 percent will lead to a decrease in the number of milkfish bacteria (Yuliani et al., 2017).

Chicken meat contains high, complete and balanced nutritional contents (Beski et al., 2015) and the price is relatively economical. The high nutritional content in chicken meat is a good medium for microbial growth, therefore chicken meat is one of the perishable foodstuffs. Decomposition on chicken meat can be caused by physical collisions, chemical changes, and microbial activity. As a result of the decomposition caused by bacteria, cause mucus formation, change in color, change in odor, and change in taste. Alpinia purpurata (Vieill.) K. Schum contains ingredients that can be used to inhibit bacteria (Rialita et al., 2019). One method to maintain quality is by giving natural preservatives such as Alpinia purpurata (Vieill.) K. Schum to inhibit bacterial growth (Kochuthressia et al., 2010).

Red ginger fried chicken is a traditional dish from West Java that is marinated with a plentiful red ginger or Alpinia purpurata (Vieill.) K. Schum. Red ginger fried chicken has a delicious taste and distinctive aroma. Apart from being a spice, Alpinia purpurata (Vieill.) K. Schum can also be used as a topping that can be eaten together with the meat and has the potential to be preserved because it is made from the spice Alpinia purpurata (Vieill.) K. Schum.

\section{Method}

This research was a quantitative experimental study using a Completely Randomized Factorial Design (CRFD) experimental procedure. The treatment given was the addition of Alpinia purpurata (Vieill.) K. Schum with a concentration of 0 percent, 10 percent, 20 percent, 30 percent and 40 percent, then the number of bacteria, antioxidant capacity, and organoleptic properties were examined. The raw materials used in the making of Red Ginger fried chicken were red ginger (Alpinia purpurata (Vieill.) K. Schum), chicken, shallots, garlic, coriander, candlenut, turmeric, bay leaves, lemongrass, pepper and salt. Materials used for the analysis of antioxidant capacity were methanol and DPPH solution. While the materials used for the analysis of the number of bacteria were plate count agar (PCA) media and butterfield's phosphate buffered solution. The tools used in the process of making Red Ginger (Alpinia purpurata (Vieill.) K. Schum) fried chicken were a knife, cutting board, basin, scale, grate, spoon, spatula, plan and stove. The tools used for chemical analysis were digital scales, measuring flasks, pipettes, spectrophotometers, scales, autoclaves, incubators, anaerobic jars, petri dishes, retail bottles, colony counters, blenders, jars, bent glass rods and glass pipettes.

Hedonic test employed a scale of 1 (not prefer) to 5 (prefer). The hedonic test was carried out to determine the level of preference for the panelists on the taste, color and aroma in the addition of Alpinia purpurata (Vieill.) K. Schum with a concentration of 0 percent, 10 percent, 20 percent, 30 percent, and 40 percent in Red Ginger (Alpinia purpurata (Vieill.) K. Schum) fried chicken. The panelists involved were 35 students of the State University of Malang with two repetitions. Statistical analysis of the research data from two repetitions were statistically analyzed using the Two-Way Anova method. Two-Way Anova was used to test for real differences between two variants of three or more sample groups due to the presence of two treatment factors. If there is a difference in treatment, then it is continued by the Duncan's Multiple Range Test (DMRT) with a significance level of 5 percent.

\section{Results and Discussion}

\section{A. The Analysis Results on The Number of Bacteria on Red Ginger (Alpinia purpurata (Vieill.) K. Schum) fried chicken}

The analysis indicated that the higher the addition of Alpinia purpurata (Vieill.) K. Schum used on Red Ginger nfried chicken, the lower the number of bacteria. Alpinia purpurata (Vieill.) K. Schum red is able to inhibit bacterial growth, particularly against Enterobacter aerogenes (Kochuthressia et al., 2010; Soares et al., 2018). The low number of bacteria in the addition of Alpinia purpurata (Vieill.) K. Schum which was greater is due to the content of active compounds as antimicrobials (Al-Enazi, 2018). One of the chemical compounds found in Alpinia purpurata 
(Vieill.) K. Schum is essential oil (Santos et al., 2012). Essential oils have antifungal and antibacterial activity (Kalemba \& Kunicka, 2005). The results of Kochuthressia et al., (2010) stated that the effect of using a high dose of Alpinia purpurata (Vieill.) K. Schum in immersing milkfish is able to reduce the number of bacteria in milkfish. This shows that the addition of more Alpinia purpurata (Vieill.) K. Schum is able to inhibit the number of bacteria present.

Alpinia purpurata (Vieill.) K. Schum contains compounds that is able to inhibit bacteria (Raj et al., 2012). The rhizome juice of Alpinia purpurata (Vieill.) K. Schum has bacteriostatic and bactericidal activities against Aeromonas hydrophila bacteria (Raj et al., 2012), while 10.35508/ljch.v1i2.2159 states that the extract of Alpinia purpurata (Vieill.) K. Schum red (Alpinia purpurata (Vieill.) K. Schum) is more effective in inhibiting the growth of S.aureus bacteria compared to E. coli (Kochuthressia et al., 2010; Villaflores et al., 2010).

Based on the results of the data obtained during the storage period, it can be seen that the lowest number of bacteria was the addition of 40 percent of Alpinia purpurata (Vieill.) K. Schum. This is because Alpinia purpurata (Vieill.) K. Schum is able to act as a preservative substance thus the number of bacteria found in Red Ginger fried chicken has decreased. The role of Alpinia purpurata (Vieill.) K. Schum as a food preservative is inseparable from the ability of Alpinia purpurata (Vieill.) K. Schum, which has antimicrobial activity of phenols, flavonoids and essential oils which are antimicrobial sources (de Pooter et al., 1995; Santos et al., 2012). Alpinia purpurata (Vieill.) K. Schum is added, the higher the antimicrobial content (Victório et al., 2009), where as Santos et al., (2012) states that the effect of adding Alpinia purpurata (Vieill.) K. Schum on mackerel is able to increase storage period. The number of bacteria on Red Ginger (Alpinia purpurata (Vieill.) K. Schum) fried chicken can be seen from the results of research after the it received the addition of Alpinia purpurata (Vieill.) K. Schum. From the results of the data, it can be seen that the average number of bacteria at the highest storage period was in the control (without the addition of Alpinia purpurata (Vieill.) K. Schum). After adding Alpinia purpurata (Vieill.) K. Schum, there was a decrease in the number of bacteria on Red Ginger fried chicken in each addition to the concentration of Alpinia purpurata (Vieill.) K. Schum, accordingly it would affect its durability of Red Ginger (Alpinia purpurata (Vieill.) K. Schum) fried chicken.

\section{B. The Analysis Results of Antioxidant Capacity of Red Ginger (Alpinia purpurata (Vieill.) K. Schum) fried chicken}

The higher the addition of Alpinia purpurata (Vieill.) K. Schum, it obtained higher antioxidant capacity (the resulting IC50 value decreased). In the rhizome of red Alpinia purpurata (Vieill.) K. Schum (Alpinia purpurata (Vieill.) K. Schum), it contains phenolic compounds and flavonoids which can be used as a source of natural antioxidants (Fachriyah et al., 2020; Victório et al., 2009).

Based on the results of the data obtained on the storage period, the highest antioxidant capacity was in the addition of 40 percent of Alpinia purpurata (Vieill.) K. Schum. On day 0, the antioxidant capacity of Red Ginger fried chicken with the addition of Alpinia purpurata (Vieill.) K. Schum 40 percent was $102.51 \mathrm{ppm}$, on day 1 the antioxidant activity was $104.15 \mathrm{ppm}$, on day 2 the antioxidant activity was $105.86 \mathrm{ppm}$. The highest antioxidant capacity in Red Ginger fried chicken with the addition of Alpinia purpurata (Vieill.) K. Schum 40 percent, namely on day 0 and decreased on days 1 and 2. Red Alpinia purpurata (Vieill.) K. Schum rhizome contains flavonoids which consist of a collection of polyphenolic compounds with high antioxidant content (Fachriyah et al., 2018). Antioxidants are compounds that are easily damaged by oxidation (Obeng et al., 2020). On the 1st and 2nd day of storage, the antioxidant capacity decreased since the antioxidant capacity was oxidized due to the presence of light and air. Antioxidant capacity is a compound that is susceptible to being oxidized by effects such as light, heat or directly reacting with oxygen accordingly the value of antioxidant capacity has decreased (Shahidi, 2015).

\section{Hedonic Properties (Preferences) of Red Ginger (Alpinia purpurata (Vieill.) K. Schum) fried chicken}

The taste, aroma, color and appearance of a food will affect the level of people's preference for food (Barrett et al., 2010). The taste of food is influenced by several factors, including chemical compounds, temperature, concentration and interactions with other taste components. Taste involves more of the five senses, that is to say the tongue (Caballero et al., 2003). Based on the results of the study, there is a significant difference in the effect of using Alpinia purpurata (Vieill.) K. Schum $0 \%, 10 \%, 20 \%, 30 \%$ and $40 \%$ on the taste hedonic properties of Red Ginger fried chicken. The 
highest preference of panelists for the hedonic properties of Red Ginger fried chicken is the addition of Alpinia purpurata (Vieill.) K. Schum 40 percent. Based on the results of the study, the higher the addition of Alpinia purpurata (Vieill.) K. Schum was added, the level of preference for the taste of Red Ginger fried chicken was increasing.

The aroma of food determines the delicacy of these food ingredients, in this case the aroma involves more of the five senses, that is to say the nose (Hadanu \& Lomo, 2019). The highest preference of panelists to the hedonic properties of the Red Ginger fried chicken was obtained from the addition of 40 percent of Alpinia purpurata (Vieill.) K. Schum. The most preferred level of Red Ginger fried chicken was the highest addition of Alpinia purpurata (Vieill.) K. Schum, this is because Alpinia purpurata (Vieill.) K. Schum adds a distinctive aroma to Red Ginger fried chicken. Alpinia purpurata (Vieill.) K. Schum contains terpenoid compounds in essential oils that give a dish a distinctive aroma (Souza et al., 2018).

Visually, the color factor generally determines the quality of a food (Brosnan \& Sun, 2004; Clydesdale, 1991). The color of the Red Ginger fried chicken comes from the number of Alpinia purpurata (Vieill.) K. Schum added. Alpinia purpurata (Vieill.) K. Schum gives a brownish color to Red Ginger fried chicken due to the maillard reaction process, the reaction that occurs between carbohydrates and proteins that are heated simultaneously (Zhang et al., 2009). The panelists' preference for the hedonic properties of the highest color was the Red Ginger fried chicken with the addition of 40 percent of Alpinia purpurata (Vieill.) K. Schum. The highest addition of Alpinia purpurata (Vieill.) K. Schum makes the Red Ginger fried chicken becomes more brown in color.

\section{Conclusion}

Based on the results of research and discussion, it can be concluded that there is an influence on the use of different percentages of Alpinia purpurata (Vieill.) K. Schum on the number of bacteria on day 0,1,2 in Red Ginger fried chicken. Panelists' preferences for the taste, aroma, and color of red galangal fried chicken were not influenced by the percentage of Alpinia purpurata (Vieill.) K. Schum usage. The number of bacteria, antioxidant capacity, and organoleptic properties of Red Ginger fried chicken, it can be suggested that further research needs to be conducted on the addition of Alpinia purpurata (Vieill.) K. Schum in inhibiting the number of bacteria in Red Ginger fried chicken with a greater concentration. The addition of Alpinia purpurata (Vieill.) K. Schum 40 percent is able to inhibit the number of bacteria on day 0.1 and 2 lower.

\section{References}

Al-Enazi, N. M. (2018). Phytochemical screening and biological activities of some species of alpinia and Convolvulus plants. International Journal of Pharmacology, 14(3), 301-309. https://doi.org/10.3923/ijp.2018.301.309

Barrett, D. M., Beaulieu, J. C., \& Shewfelt, R. (2010). Color, flavor, texture, and nutritional quality of freshcut fruits and vegetables: Desirable levels, instrumental and sensory measurement, and the effects of processing. Critical Reviews in Food Science and Nutrition, 50(5), 369-389. https://doi.org/10.1080/10408391003626322

Beski, S. S. M., Swick, R. A., \& Iji, P. A. (2015). Specialized protein products in broiler chicken nutrition: A review. In Animal Nutrition (Vol. 1, Issue 2, pp. 47-53). KeAi Communications Co. https://doi.org/10.1016/j.aninu.2015.05.005

Brosnan, T., \& Sun, D. W. (2004). Improving quality inspection of food products by computer vision - A review. In Journal of Food Engineering (Vol. 61, Issue 1 SPEC., pp. 3-16). Elsevier Ltd. https://doi.org/10.1016/S0260-8774(03)00183-3

Caballero, B., Trugo, L., \& Finglas, P. (2003). Encyclopedia of Food Sciences and Nutrition (B. Caballero (ed.)). Science Direct. https://www.sciencedirect.com/referencework/9780122270550/encyclopedia-offood-sciences-and-nutrition

Chan, E. W. C., \& Wong, S. K. (2015). Phytochemistry and pharmacology of ornamental gingers, Hedychium coronarium and Alpinia purpurata: A review. In Journal of Integrative Medicine (Vol. 13, Issue 6, pp. 368-379). Elsevier (Singapore) Pte Ltd. https://doi.org/10.1016/S2095-4964(15)60208-4

Clydesdale, F. M. (1991). Color perception and food quality. Journal of Food Quality, 14(1), 61-74. https://doi.org/10.1111/j.1745-4557.1991.tb00047.x

de Cuffa Matusaiki, C., Ferreira, R. G., Otutumi, L. K., dos Santos, I. C., Pereira Ramos, F. A., Mezalira, T. S., Jacomassi, E., Barbosa, L. N., Gonçalves, D. D., \& Soares, A. A. (2021). Antibiotic resistance profile of gram-negative bacteria isolated from dog nasal swab samples, and antibacterial and 
antioxidant activities of aqueous extracts of Alpinia purpurta (Vieill.) K. Schum (Zingiberaceae). Semina:Ciencias Agrarias, 42(1), 179-192. https://doi.org/10.5433/1679-0359.2021v42n1p179

de Pooter, H. L., Aboutabl, E. A., \& El-Shabrawy, A. O. (1995). Chemical composition and antimicrobial activity of essential oil of leaf, stem and rhizome of Alpinia speciosa. Flavour and Fragrance Journal, 10(2), 63-67. https://doi.org/10.1002/ffj.2730100202

Fachriyah, E., Kusrini, D., Haryanto, I. B., Wulandari, S. M. B., Lestari, W. I., \& Sumariyah, S. (2020). Phytochemical test, determination of total Phenol, total Flavonoids and antioxidant activity of Ethanol extract of Moringa Leaves (Moringa oleifera Lam). Jurnal Kimia Sains Dan Aplikasi, 23(8), 290-294. https://doi.org/10.14710/jksa.23.8.290-294

Fachriyah, E., Kusrini, D., \& Wibawa, P. J. (2018). Improvement of bioactivity with nanoparticle fabrication: Cytotoxic test of Ethanol, n-Hexane and Ethyl Acetate extract from Red Galangal Rhizome (Alpinia purpurata (Vieill.) K. Schum) in bulk and nanoparticle size using BSLT method. Jurnal Kimia Sains Dan Aplikasi, 21(1), 39-43. https://doi.org/10.14710/jksa.21.1.39-43

Ghosh, S., \& Rangan, L. (2013). Alpinia: The gold mine of future therapeutics. 3 Biotech, 3(3), 173-185. https://doi.org/10.1007/s13205-012-0089-x

Hadanu, R., \& Lomo, C. P. (2019). Organoleptic test analysis and effect of liquid smoke concentration on smoked fish. IOP Conference Series: Earth and Environmental Science, 382(1), 012017. https://doi.org/10.1088/1755-1315/382/1/012017

Kalemba, D., \& Kunicka, A. (2005). Antibacterial and antifungal properties of essential oils. Current Medicinal Chemistry, 10(10), 813-829. https://doi.org/10.2174/0929867033457719

Kochuthressia, K., Britto, S., Jaseentha, M., Raj, L., \& Senthilkumar, S. (2010). Antimicrobial efficacy of extracts from Alpinia purpurata (Vieill.) K.Schum. against human pathogenic bacteria and fungi. Agriculture and Biology Journal of North America, 1(6), 1249-1252. https://doi.org/10.5251/abjna.2010.1.6.1249.1252

Lobo, V., Patil, A., Phatak, A., \& Chandra, N. (2010). Free radicals, antioxidants and functional foods: Impact on human health. Pharmacognosy Reviews, 4(8), 118-126. https://doi.org/10.4103/09737847.70902

Obeng, E., Kpodo, F. M., Tettey, C. O., Essuman, E. K., \& Adzinyo, O. A. (2020). Antioxidant, total phenols and proximate constituents of four tropical leafy vegetables. Scientific African, 7, e00227. https://doi.org/10.1016/j.sciaf.2019.e00227

Raj, C. A., Sophia, D., Ragavendran, P., Starlin, T., Rathi, M. A., \& Gopalakrishnan, V. K. (2012). Leaf extract of Alpinia purpurata (Vieill.) K. Schum screened for its phytochemical constituents and antibacterial and anticancer activities. Journal of Chinese Integrative Medicine, 10(12), 1460-1464. https://doi.org/10.3736/jcim20121219

Rialita, T., Radiani, H., \& Alfiah, D. (2019). Antimicrobial activity of the combination of red galangal (Alpinia purpurata K. Schum) and cinnamon (Cinnamomum burmanii) essential oils on Escherichia coli and Staphylococcus aureus bacteria. Journal of Physics: Conference Series, 1217(1), 12132. https://doi.org/10.1088/1742-6596/1217/1/012132

Santos, G. K. N., Dutra, K. A., Barros, R. A., da Câmara, C. A. G., Lira, D. D., Gusmão, N. B., \& Navarro, D. M. A. F. (2012). Essential oils from Alpinia purpurata (Zingiberaceae): Chemical composition, oviposition deterrence, larvicidal and antibacterial activity. Industrial Crops and Products, 40(1), 254260. https://doi.org/10.1016/j.indcrop.2012.03.020

Shahidi, F. (2015). Antioxidants: Principles and applications. In Handbook of Antioxidants for Food Preservation (pp. 1-14). Elsevier Inc. https://doi.org/10.1016/B978-1-78242-089-7.00001-4

Soares, A. A., Jacomassi, E., Da Mata, R., Lopes, K. F. C., Borges, J. L., De Pádua Pereira, U., De Melo Germano, R., Otutumi, L. K., De Almeida Martins, L., \& Gonçalves, D. D. (2018). Antimicrobial activity of species Zingiber offcinale Roscoe and Alpinia purpurata (Vieill.) K. Schum. (Zingiberaceae)-Review. In Semina: Ciencias Agrarias (Vol. 39, Issue 4, pp. 1849-1861). Universidade Estadual de Londrina. https://doi.org/10.5433/1679-0359.2018v39n4p1849

Souza, T. D. A. D., Lopes, M. B., Ramos, A. D. S., Ferreira, J. L. P., Silva, J. R. D. A., Queiroz, M., Araújo, K. G. D. L., \& Amaral, A. C. F. (2018). Alpinia essential oils and their major components against Rhodnius nasutus, a vector of chagas disease. The Scientific World Journal, 2018, 2393858. https://doi.org/10.1155/2018/2393858

Tungmunnithum, D., Thongboonyou, A., Pholboon, A., \& Yangsabai, A. (2018). Flavonoids and other phenolic compounds from medicinal plants for pharmaceutical and medical aspects: An overview. Medicines, 5(3), 93. https://doi.org/10.3390/medicines5030093

Victório, C. P., Kuster, R. M., \& Lage, C. L. S. (2009). Detection of flavonoids in Alpinia purpurata (Vieill.) K. Schum. leaves using highperformance liquid chromatography. Revista Brasileira de Plantas Medicinais, 11(2), 147-153. https://doi.org/10.1590/S1516-05722009000200006

Villaflores, O. B., MacAbeo, A. P. G., Gehle, D., Krohn, K., Franzblau, S. G., \& Aguinaldo, A. M. (2010). 
Phytoconstituents from Alpinia purpurata and their in vitro inhibitory activity against Mycobacterium tuberculosis. Pharmacognosy Magazine, 6(24), 339-344. https://doi.org/10.4103/0973-1296.71785

Yuliani, N., Syawaalz, A., \& Lisna, M. (2017). Ekstraksi dan identifikasi pendahuluan golongan senyawa fenol dari rimpang lengkuas merah (Alpinia Purpurata (Vieill) k. Sch. Jurnal Sains Natural, 1(2), 111. https://doi.org/10.31938/jsn.v1i2.19

Zhang, Q., Ames, J. M., Smith, R. D., Baynes, J. W., \& Metz, T. O. (2009). A Perspective on the maillard reaction and the analysis of Protein Glycation by Mass Spectrometry: Probing the pathogenesis of chronic disease. Journal of Proteome Research, 8(2), 754-769. https://doi.org/10.1021/pr800858h 